IFAS Extension

\title{
Creating and Working with Rubrics ${ }^{1}$
}

Aubrey L. Stoughton and Brian E. Myers ${ }^{2}$

Rubrics are tools created to help assess student performance in a more reliable, objective, and consistent manner. Rubrics are particularly helpful in situations where there is not always a right or a wrong way or where grading can become subjective. A rubric establishes guidelines and point values to help students understand what to expect and also helps the instructor remain consistent throughout the grading process.

When creating an assignment teachers generally consider what they would ideally see when the students complete an assignment. A rubric documents these thoughts and assesses a point value to correspond with each expectation. Rubrics are also a useful way to ensure that course assignments are consistent with course objectives and state standards.

\section{Types of Rubric}

There are two main types of rubrics: generic and task specific. Generic rubrics generally evaluate a broader spectrum of assessment where students are encouraged or expected to have more breadth in their final products, such as a agriscience fair portfolios. Task specific rubrics look at the particular behaviors to be assessed, such as the creation of a woodworking project.

Under these two main categories there are two subcategories, analytic and holistic. An analytic rubric examines the individual details of a performance or assignment and focuses on the end product, such as a rubric evaluating a livestock pen design project. Teachers determine the criteria that represents high quality performance, such as functionality, convenience, durability, design rationale, and technical ability. Each of these main criteria may be comprised of specific elements which each have a corresponding point value.

1. This document is AEC388, one of a series of the Agricultural Education and Communication Department, Florida Cooperative Extension Service, Institute of Food and Agricultural Sciences, University of Florida. Original publication date May 2008. Visit the EDIS Web Site at http://edis.ifas.ufl.edu.

2. Aubrey L. Stoughton, graduate teaching and research assistant; Brian E. Myers, assistant professor, Department of Agricultural Education and Communication; Florida Cooperative Extension Service, Institute of Food and Agricultural Sciences, University of Florida, Gainesville, FL 32611-0290. 


\section{Figure 1. Types of Rubrics}

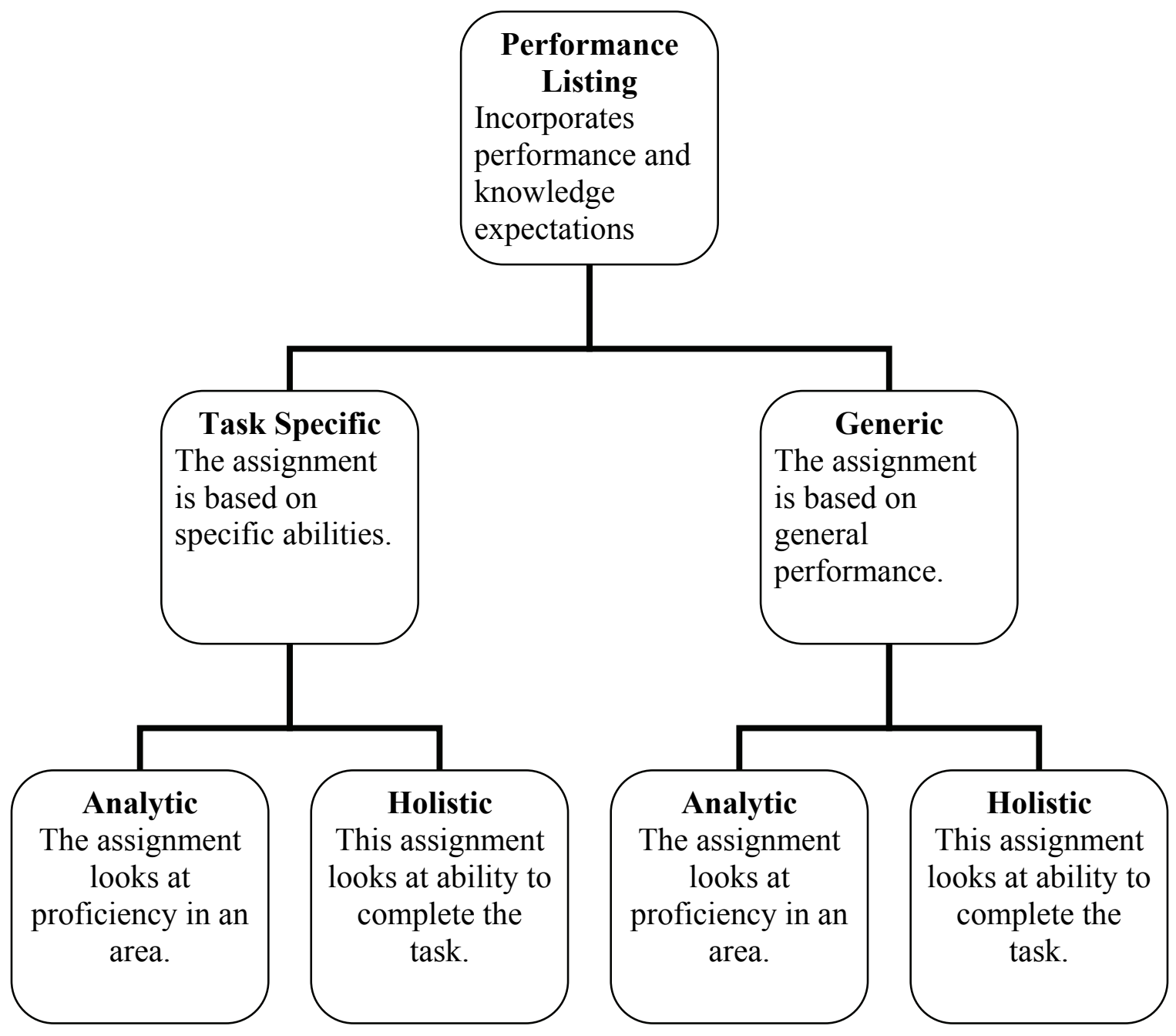

A holistic rubric focuses more on process, and typically follows a "yes or no" format, evaluating whether the student completed each step in the process or not. Insert Figure 3. In the example, the assignment to administer an equine vaccine can only be passed by successfully completing each step in the process.

Figure 2. Sample Analytic Rubric

\section{Ex. Functionality (35 points)}

Pen allows for animals to be gathered and contained.

All gates are in appropriate areas.

All areas are accessible in case of emergency.

Animals can be separated, if necessary.

Animals can be restrained properly. 


\section{Convenience (20 points)}

Working in pens requires minimum effort.

Pens are easy to maintain and repair.

Animals can be worked with minimal stress

\section{Species Appropriate (20 points)}

Takes farm and animals worked into consideration

Appropriately sized and equipped for desired species

Takes into account special needs associated with different species

\section{Design Rationale (20 points)}

Students show an understanding of the function of the pens and why their design incorporates the characteristics it does.

Explanation of design is clear and cohesive.

\section{Technical ability (5pts)}

Design is appropriately laid out and easy to follow.

Professional in appearance (lines, color, and labeling are clear, crisp, and easy to see.)

\section{Figure 3. Sample Holistic Rubric}

Equine Vaccination (50 points, must pass all aspects 50 or 0 )

\begin{tabular}{|l|l|l|}
\hline Task & Yes & No \\
\hline Was vaccine kept cold prior to drawing up? & & \\
\hline Was injection site cleansed? & & \\
\hline $\begin{array}{l}\text { Was injection given in the correct triangular area of the neck or the } \\
\text { buttock? }\end{array}$ & & \\
\hline $\begin{array}{l}\text { Did the student draw back to check for blood prior administering the } \\
\text { vaccine? }\end{array}$ & & \\
\hline
\end{tabular}




\section{Creating Your Own Rubric}

The main element to consider in choosing which type of rubric to use is its purpose. There are no rules to building a rubric as long as it serves the function for which it is intended. Here are a few guidelines, however, for creating a new rubric::

Step1: Make a list of the criteria for the assignment. This might include format, topics, proficiencies, steps, or any other criteria.

Step 2: Assign a point value for each criterion.

Step 3: Design a format that contains all needed student information, clearly conveys performance expectations, and makes it grade entry easy.

Step 4: Create a matrix that correlates a behavior with a point value for each competency.

There are many tools on the Internet designed to help generate rubrics and to provide examples. The following websites help teachers create their own rubrics based on content and subject:

\section{Rubistar \\ http://rubistar.4teachers.org/index.php \\ Rubric Machine \\ http://landmark-project.com/rubric builder/index.php}

Teachnology

http:/www.teach-nology.com/web tools/rubrics/

Once you are comfortable with the general rubric design, you can also easily create your own rubric in a Word document or Excel file.

The use of rubrics allows for a greater accountability and reliability in grading and offers a structure and guidance to students as they create their projects. Working with such a tool enables teachers to quickly grade assignments and remain objective in their grading. 
Figure 4. Website-Generated Rubric

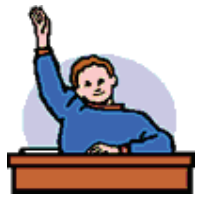

Name:

\section{University of Florida Class participation}

\begin{tabular}{|c|c|c|c|c|c|}
\hline & \multicolumn{4}{|c|}{ Criteria } & Points \\
\hline & 4 & 3 & 2 & 1 & \\
\hline $\begin{array}{l}\text { Attendance / } \\
\text { Promptness }\end{array}$ & $\begin{array}{l}\text { Student is } \\
\text { always prompt } \\
\text { and regularly } \\
\text { attends classes. }\end{array}$ & $\begin{array}{l}\text { Student is late to } \\
\text { class once } \\
\text { every two } \\
\text { weeks and } \\
\text { regularly attends } \\
\text { classes. }\end{array}$ & $\begin{array}{l}\text { Student is late to } \\
\text { class more than } \\
\text { once every two } \\
\text { weeks and } \\
\text { regularly attends } \\
\text { classes. }\end{array}$ & $\begin{array}{l}\text { Student is late } \\
\text { to class more } \\
\text { than once a } \\
\text { week and/or } \\
\text { has poor } \\
\text { attendance of } \\
\text { classes. }\end{array}$ & \\
\hline $\begin{array}{c}\text { Level Of } \\
\text { Engagement In } \\
\text { Class }\end{array}$ & $\begin{array}{l}\text { Student } \\
\text { proactively } \\
\text { contributes to } \\
\text { class by offering } \\
\text { ideas and asking } \\
\text { questions more } \\
\text { than once per } \\
\text { class. }\end{array}$ & $\begin{array}{l}\text { Student } \\
\text { proactively } \\
\text { contributes to } \\
\text { class by offering } \\
\text { ideas and } \\
\text { asking questions } \\
\text { once per class. }\end{array}$ & $\begin{array}{l}\text { Student rarely } \\
\text { contributes to } \\
\text { class by offering } \\
\text { ideas and asking } \\
\text { questions. }\end{array}$ & $\begin{array}{l}\text { Student never } \\
\text { contributes to } \\
\text { class by } \\
\text { offering ideas } \\
\text { and asking } \\
\text { questions. }\end{array}$ & \\
\hline Listening Skills & $\begin{array}{l}\text { Student listens } \\
\text { when others talk, } \\
\text { both in groups } \\
\text { and in class. } \\
\text { Student } \\
\text { incorporates or } \\
\text { builds off of the } \\
\text { ideas of others. }\end{array}$ & $\begin{array}{l}\text { Student listens } \\
\text { when others } \\
\text { talk, both in } \\
\text { groups and in } \\
\text { class. }\end{array}$ & $\begin{array}{l}\text { Student does not } \\
\text { listen when } \\
\text { others talk, both } \\
\text { in groups and in } \\
\text { class. }\end{array}$ & $\begin{array}{l}\text { Student does } \\
\text { not listen when } \\
\text { others talk, } \\
\text { both in groups } \\
\text { and in class. } \\
\text { Student often } \\
\text { interrupts } \\
\text { when others } \\
\text { speak. }\end{array}$ & \\
\hline Behavior & $\begin{array}{l}\text { Student almost } \\
\text { never displays } \\
\text { disruptive } \\
\text { behavior during } \\
\text { class. }\end{array}$ & $\begin{array}{l}\text { Student rarely } \\
\text { displays } \\
\text { disruptive } \\
\text { behavior during } \\
\text { class. }\end{array}$ & $\begin{array}{l}\text { Student } \\
\text { occasionally } \\
\text { displays } \\
\text { disruptive } \\
\text { behavior during } \\
\text { class. }\end{array}$ & $\begin{array}{l}\text { Student almost } \\
\text { always } \\
\text { displays } \\
\text { disruptive } \\
\text { behavior during } \\
\text { class. }\end{array}$ & \\
\hline Preparation & $\begin{array}{l}\text { Student is almost } \\
\text { always prepared } \\
\text { for class with } \\
\text { assignments and } \\
\text { required class } \\
\text { materials. }\end{array}$ & $\begin{array}{l}\text { Student is } \\
\text { usually } \\
\text { prepared for } \\
\text { class with } \\
\text { assignments } \\
\text { and required } \\
\text { class materials. }\end{array}$ & $\begin{array}{l}\text { Student is rarely } \\
\text { prepared for } \\
\text { class with } \\
\text { assignments and } \\
\text { required class } \\
\text { materials. }\end{array}$ & $\begin{array}{l}\text { Student is } \\
\text { almost never } \\
\text { prepared for } \\
\text { class with } \\
\text { assignments } \\
\text { and required } \\
\text { class materials. }\end{array}$ & \\
\hline & & & & Total----> & \\
\hline
\end{tabular}

\section{Teacher Comments:}

